2000s-31

\title{
IT Outsourcing Risk Management at British Petroleum
}

Benoit A. Aubert, Michel Patry, Suzanne Rivard, Heather Smith

Série Scientifique

Scientific Series

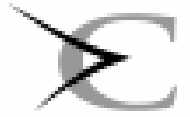

Montréal

Septembre 2000 


\section{CIRANO}

Le CIRANO est un organisme sans but lucratif constitué en vertu de la Loi des compagnies du Québec. Le financement de son infrastructure et de ses activités de recherche provient des cotisations de ses organisationsmembres, d'une subvention d'infrastructure du ministère de la Recherche, de la Science et de la Technologie, de même que des subventions et mandats obtenus par ses équipes de recherche.

CIRANO is a private non-profit organization incorporated under the Québec Companies Act. Its infrastructure and research activities are funded through fees paid by member organizations, an infrastructure grant from the Ministère de la Recherche, de la Science et de la Technologie, and grants and research mandates obtained by its research teams.

\section{Les organisations-partenaires / The Partner Organizations}

-École des Hautes Études Commerciales

-École Polytechnique

-Université Concordia

-Université de Montréal

-Université du Québec à Montréal

-Université Laval

-Université McGill

-MEQ

-MRST

-Alcan Aluminium Ltée

-AXA Canada

-Banque Nationale du Canada

-Banque Royale du Canada

-Bell Québec

-Bombardier

-Bourse de Montréal

-Développement des ressources humaines Canada (DRHC)

-Fédération des caisses populaires Desjardins de Montréal et de l'Ouest-du-Québec

-Hydro-Québec

-Imasco

-Industrie Canada

-Pratt \& Whitney Canada Inc.

-Raymond Chabot Grant Thornton

-Ville de Montréal

(c) 2000 Benoit A. Aubert, Michel Patry, Suzanne Rivard et Heather Smith. Tous droits réservés. All rights reserved. Reproduction partielle permise avec citation du document source, incluant la notice ( ).

Short sections may be quoted without explicit permission, provided that full credit, including ( $)$ notice, is given to the source.

Ce document est publié dans l'intention de rendre accessibles les résultats préliminaires de la recherche effectuée au CIRANO, afin de susciter des échanges et des suggestions. Les idées et les opinions émises sont sous l'unique responsabilité des auteurs, et ne représentent pas nécessairement les positions du CIRANO ou de ses partenaires.

This paper presents preliminary research carried out at CIRANO and aims at encouraging discussion and comment. The observations and viewpoints expressed are the sole responsibility of the authors. They do not necessarily represent positions of CIRANO or its partners.

\section{ISSN 1198-8177}




\title{
IT Outsourcing Risk Management at British Petroleum*
}

\author{
Benoit A. Aubert ${ }^{\dagger}$, Michel Patry ${ }^{\ddagger}$, Suzanne Rivard ${ }^{\S}$, Heather Smith ${ }^{\text {It }}$
}

\section{Résumé / Abstract}

Ce document présente les résultats d'une étude de trois contrats d'impartition successifs. L'étude fut conduite chez British Petroleum. Une définition opérationnelle du risque d'impartition est donnée. Cette définition est ensuite utilisée pour déterminer le niveau de risque associé à chacun des contrats. Les mécanismes de gestion de risque sont également identifiés. Les résultats démontrent qu'une gestion active du risque permet de réduire sensiblement les niveau d'exposition au risque, notamment dans le cas de contrats d'impartition des technologies de l'information.

This paper reports the results of a study of three successive IT outsourcing contracts at British Petroleum (BP). We offer an operational definition of IT outsourcing risk and use it to assess the risk exposure associated with each contract. We then examine how the management at BP dealt with outsourcing risk. Our results show that careful and deliberate risk management can substantially attenuate the level of risk exposure, and that IT outsourcing risks can be managed.

Mots Clés : Impartition des systèmes informatiques, gestion du risque d'impartition, gestion du risque, théories de l'agence et des coûts de transaction, étude de cas

Keywords: Outsourcing of IS, IS risk management, agency theory, transaction cost economics, case study

\footnotetext{
* Corresponding Author: Benoit A. Aubert, CIRANO, 2020 University Street, $25^{\text {th }}$ floor, Montréal, Qc, Canada H3A 2A5 Tel.: (514) 985-4024 Fax: (514) 985-4039 email: aubertb@cirano.umontreal.ca We wish to thank

† École des Hautes Études Commerciales and CIRANO

¥ École des Hautes Études Commerciales and CIRANO

$\S$ École des Hautes Études Commerciales and CIRANO

"Queen's University
} 


\section{Introduction}

"Risk is a choice rather than a fate"

Peter Bernstein $[9, \mathrm{p} .8]$

Bernstein's history of man's effort to understand risk begins with the following question : "What is it that distinguishes the thousands of years of history from what we think of as modern times?" to which the following answer is provided: "The revolutionary idea that defines the boundary between modern times and the past is the mastery of risk: the notion that the future is more than a whim of the gods, and that men and women are not passive before nature" [9, p.1]. The question and its answer could be transposed to the context of the management of Information Technology (IT) outsourcing. While, a decade ago, firms considering to outsource their IT activities were often portrayed as facing numerous and important risks against which little could be done [14], there are now examples that show that these risks can be managed [4].

Using a risk management framework advanced by Aubert et al. [4], this paper reports the results of a study of three successive IT outsourcing contracts at British Petroleum (BP). The paper illustrates how risk management and learning can eventually transform risk into a "choice" rather than a "fate".

The paper first defines the notions of IT outsourcing risk and risk management and describes the methodology adopted to conduct the study. It then describes each of the three BP IT outsourcing contracts, along with an assessment of respective risk level and an analysis of how risk was managed in each case. Finally, a transversal analysis of the three contracts is conducted in order to contrast and compare them.

\section{IT outsourcing risk and risk management}

March and Shapira define risk from two broad perspectives: the economic perspective and the managerial perspective [20]. The economic perspective defines risk as the variance of the probability distribution of possible gains and losses associated with a particular alternative [5]. The managerial perspective considers the notion of risk differently [20]. Managers do not equate the risk of an alternative with the variance of the probability distribution of possible outcomes, and they do not treat uncertainty about positive outcomes as an important aspect of risk. Rather, to them, the potential positive outcomes constitute the attractiveness of an alternative, while risk is associated with its negative outcomes. That is, risk is perceived as a "danger or hazard". March and Shapira also emphasize the fact that, to managers, the magnitude of the loss due to a negative outcome is salient.

In order to take into account these two aspects of the managerial perspective, the risk management model advanced by Aubert et al. [5] adopts the notion of risk exposure, which is defined as a function of the probability of a negative outcome and the importance of the loss due to the occurrence of this outcome : 


$$
\text { Risk Exposure }=\mathrm{P}(\mathrm{NO}) * \mathrm{~L}(\mathrm{NO})
$$

where $\mathrm{P}(\mathrm{NO})$ is the probability of a negative outcome, and $\mathrm{L}(\mathrm{NO})$ the loss due to the outcome.

The loss due to a given undesirable outcome can be approximated either via quantitative analysis or via qualitative assessment $[7,25]$. In certain circumstances, the probability of occurrence of an undesirable outcome can be estimated on the basis of the past performance of the object under study [19]. However, in several areas such an assessment is almost impossible to perform [7]. Consequently, several risk assessment methods approximate the probability of an undesirable outcome by identifying and assessing the characteristics of a situation that are likely to influence the occurrence of the outcome $[2,7,10]$. These characteristics are labeled risk factors. This approach was adopted by Aubert et al. [5] who reviewed the IS and the industrial organization literature, and listed the most often cited undesirable outcomes of IT outsourcing, as well as their related risk factors. For the purpose of the present study, these lists were revised and updated (see Table 1).

The objective of risk management is to reduce the level of risk exposure. Aubert et al.'s [4] risk management framework defines four generic risk management strategies. The first strategy focuses on reducing the importance of the loss related to the occurrence of an undesirable outcome. Mechanisms - such as insurance, incentive contracts, bonds and warrants -which transfer to third parties the costs of coping with undesirable consequences belong to this strategy. The second strategy is the mirror image of the first : it refers to all measures aimed at reducing the probability of an undesirable outcome. This can be achieved by modifying the value of the risk factors - for example, carefully choosing the activities to be outsourced so as to reduce measurement problems or cautiously selecting suppliers with respect to their financial stability and experience with the outsourced activities. The third strategy calls for a mix of mechanisms from the two previous strategies, aimed at either reducing the likelihood of occurrence of undesirable outcomes or their consequences. Finally, the fourth strategy is a monitoring strategy, well suited to situations in which both the probability of occurrence and the losses are relatively small. Applying this strategy consists in periodically reassessing the level of risk exposure in order to determine if it has remained the same and making sure that all the "standard safeguards" are well in place.

\section{Methodology}

In order to better understand the components of risk and the dynamics of risk management, a case study was conducted. The company chosen, British Petroleum, has extensive outsourcing experience, significant contracts, and a history of risk evaluation and management. The company employs more than 50,000 people and conducts worldwide activities. Three contracts were analyzed. The first one, labeled BPX, involved the outsourcing of IT activities linked to BP Exploration division. This contract was widely publicized [11]. The second contract - BPCC was awarded a short time after BPX and included the Head Office IT needs. Finally, the BP Global contract concerns the whole IT organization (head office and divisions). 
Table 1

Components of risk exposure of IT outsourcing

\section{Undesirable outcomes}

Unexpected transition and management costs [11,13,22]

Factors leading to outcome :

- Lack of experience and expertise of the client with the activity $[13,17]$

- Lack of experience of the client with outsourcing [13]

- Uncertainty about the legal environment

Switching costs (including lock-in, repatriation and transfer to another supplier) [23]

Factors leading to outcome :

- Asset specificity [15,28]

- Small number of suppliers[21]

- Scope

- Interdependence of activities

Costly contractual amendments [13]

Factors leading to outcome :

- Uncertainty $[1,8]$

- Technological discontinuity [17]

- Task complexity

Disputes and litigation $[6,16]$

Factors leading to outcome :

- Measurement problems $[1,8]$

- Lack of experience and expertise of the client and/or of the supplier with outsourcing contracts $[13,17]$

- Uncertainty about the legal environment

- Poor cultural fit

Service debasement $[6,16]$

Factors leading to outcome :

- Interdependence of activities [5,18]

- Lack of experience and expertise of the supplier with the activity [13]

- Supplier size [13]

- Supplier financial stability [13]

- Measurement problems [1,8]

- Task complexity

Cost escalation $[16,17]$

Factors leading to outcome :

- Lack of experience and expertise of the client with contract management [13, 17]

- Measurement problems $[1,8]$

- Lack of experience and expertise of the supplier with the activity [13]

Loss of organizational competencies $[12,13,16,27]$

Factors leading to outcome :

- Scope

- Proximity of the core competencies [24]

- Interdependence of activities 
Data about the first contract were obtained from a journal article [11], internal documents produced by BP about the lessons learned from the contract, and interviews with BP managers. The BPCC contract was documented using internal documentation and interviews. Finally, the third contract, which was being negotiated at the time of data collection, was documented through interviews, internal presentations and records of meetings pertaining to the contract.

Approximately fifteen managers were interviewed. These were mostly managers from IT, involved in the first decisions and who had to manage the contracts afterward. These managers were also involved in the negotiation and risk analysis of the BP global contract. Some users from UK and the USA - were also interviewed.

Using the data gathered on the three contracts, the researchers assessed the risk level of each, by rating the risk factors and the undesirable outcomes listed in Table 1. The impact of each outcome was assessed on a 1 (very low) to 7 (very high) scale. Then, the probability of occurrence of each outcome was approximated (on a 1 to 7 scale) by first evaluating each of the risk factors associated with the outcome and then by aggregating the values of all the factors. The following section presents a brief description of each contract.

\section{Three successive IT outsourcing contracts}

\section{BPX contract.}

This was BP's first major outsourcing venture. The project covered data centre management, telecommunications, maintenance, and systems development. It was intended to cover all BP Exploration (BPX) offices around the globe, in eight major sites and 42 businesses. BPX contracted with an alliance of three suppliers. The project included a global agreement to cover the general principles and objectives of the outsourcing arrangement, which each party signed, and site-specific contracts to cover specific deliverables. A major objective of the framework was to ensure that the suppliers would act as a single "virtual supplier." Seamless service was a priority. In spite of each contractor's area of expertise, for each of the company's major business sites, one supplier would serve as the primary contractor and coordinate the services provided by the other two.

Risk exposure and risk management. Risk exposure was quite high, since most of the risk factors were present to a rather high level, and the impacts of the negative consequences were also high.

Hidden service costs was the major threat in this case (6.7,6 on Figure 1). Because of the extent of the contracts, and the large number of activities outsourced, hidden service costs could be very high (6). All three factors associated with this outcome - complexity of the outsourced activities, measurement problems, and uncertainty - were high at the outset. First, the task was very complex (6). Not only did it include all BPX IT related activities, it also included all its worldwide locations. Given the nature of the activity, measurement problems are important (7). Finally, since BPX knew its needs would change in the future but was not sure what these needs would be, uncertainty was high (7). 
Providing each supplier with a clear area of responsibilities, according to their expertise, partly decreased the value of the complexity of the task assigned to each supplier (4). To decrease the level of uncertainty, BPX decided on limited term contracts which would enable it to change technology solutions to match its business needs within a reasonable time frame. BPX also tried to reduce the likelihood that its uncertain future needs would not be met by selecting suppliers for their innovative and entrepreneurial abilities and by including expectations of best practices adoption and flexibility in the contracts (5). The general framework agreement enabled BPX to renegotiate its site performance contracts annually. Thus, the company could redefine the measures it used during the life of the general contract, hence reducing the amplitude of measurement problems (4).

Disputes and litigations, costly contractual amendments, and loss of organizational competencies were next in order of importance in terms of risk exposure $(6,5)$.

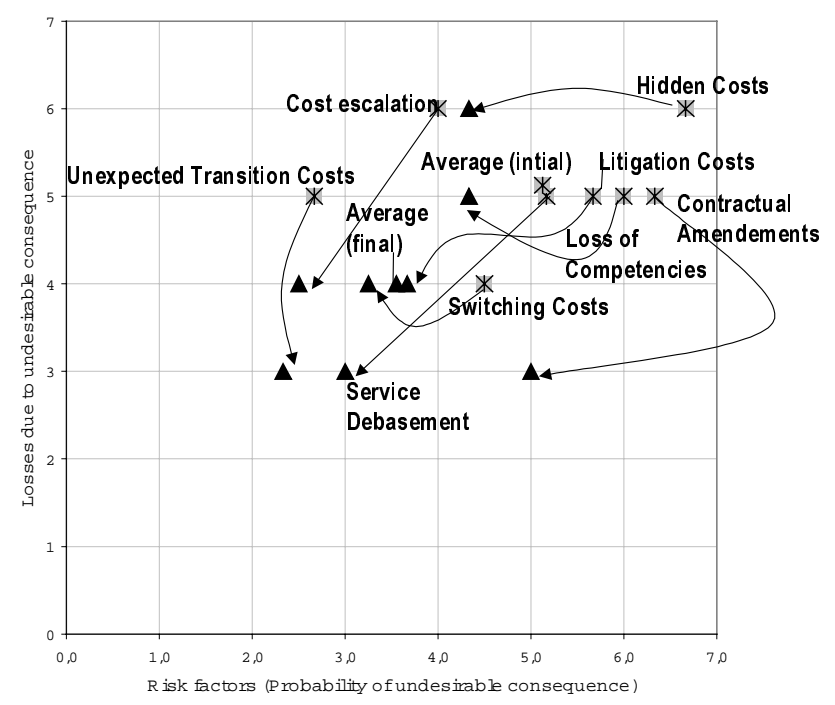

Figure 1 BPX contract

Potential disputes and litigations were evaluated thoroughly. During supplier selection, BPX realized its original idea of trying to strictly enforce seamless service between multiple suppliers through contracts was probably not possible. It recognised that disagreements would probably arise between the suppliers and that they might then turn to BPX for adjudication (6). The related risk factors are measurement problems, uncertainty about the legal environment, and poor cultural fit. The importance of measurement problems was discussed earlier. Late in the contract finalisation process, BPX uncovered a problem which it hadn't considered previously. European antitrust laws prevented the three suppliers from joining in a formal alliance as originally planned. This increased the likelihood that the suppliers would not be able to work together as planned. Instead of all three suppliers forming an alliance to work with BPX, the company was required to sign separate agreements with each. Thus, the legal environment restricted the supplier's capacity to do the job BPX needed done (4). Poor cultural fit, that is, not being able to 
work well together was seen as one of the biggest risk factors when developing this contract (6). A poor fit would increase the risk that the company would not achieve its outsourcing goals because expectations would be misaligned and/or misunderstood.

To increase its capacity to select suppliers with an appropriate level of cultural fit, BPX developed a thorough supplier selection process wherein suppliers were assessed according to qualities which BPX felt were important : innovation; flexibility; entrepreneurialism (3). BPX opted to try to reduce the impacts of disputes and litigation by asking its final list of possible suppliers to develop proposals for alliances for providing seamless service and taking joint responsibility for services. The requirement that one supplier take primary responsibility for a site was also designed to deflect the cost of disputes to the suppliers. Very little could be done to reduce the level of uncertainty of the legal environment (4).

Given the scope and complexity of the outsourcing endeavor, contractual amendments and contract renegotiation could be very costly (5). In addition to uncertainty (7) and task complexity (6) discussed earlier, technological discontinuity (6) is an important risk factor, since the contract involved both computer operations and telecommunications, and because the links between the two fields are multiplying rapidly.

Several means were put into place that would contribute to alleviate this undesirable consequence: outsourcing to several suppliers, short term contracts, and a general agreement with the possibility for each site to indicate its special requirements. The changes would presumably concern the portfolio of activities for each company (which is less costly to modify) more than the actual contract structure. The potential costs would then become lower (4). The potential impacts of technological discontinuity were reduced by minimizing possible change through a careful assessment of the I/T infrastructure needs before outsourcing and retaining responsibility for setting standards and guidelines for technology. Overall, the company felt the risk of being locked into a particular technology was greater than the risk of having to pay for unplanned future technologies if these would provide value to the company. There was a clear expectation in the contract that suppliers would work closely with BPX to identify and implement new technologies. Provided these were valuable to the company, BPX was prepared to pay the additional costs. Short term contracts was another means of alleviating the effects of technological discontinuity.

Loss of organizational competencies had a potentially high impact (5). BPX perceived human resources issues as being a major element in determining the success of this contract. The company wanted to retain good people so that needed I/T skills would not be lost. Loss of innovative capacity was considered the biggest potential loss resulting from moving so many staff out of the organization. This would probably mean that important chunks of knowledge would disappear from the firm. The related risk factors - scope, proximity to core competencies, interdependence of activities - were all relatively high. As mentioned earlier, the scope of the project was large (6). BPX had decided to become a knowledge organization and the management of information, and consequently IT activities were close to core competencies (6). The very nature of the outsourced activities is an indication of a high level of interdependence (6). 
To reduce the loss of expertise, BPX evaluated all staff prior to the transition and retained those whose skills it needed. It also negotiated that current IT staff would be hired by the suppliers to provide continuous service over the transition period. The loss of innovative capacity was a difficult element to manage. BPX recognized that no one supplier could excel in all areas and that none had access to all the high-quality technologies and services available in the marketplace. With a single supplier, the company would therefore become linked to the quality of that supplier's skills, management, technology and service know-how. Again, the consortium was the means whereby BPX could reduce this risk because several suppliers would give access to a broader array of innovative services than a single supplier. However, no supplier would have the big picture of the industry and the technology portfolio. This potential negative consequence can only be imperfectly reduced.

Service debasement could materialize in three different ways : slowdown of service, poor problem resolution, and decline in supplier staff skills ; it was perceived as serious (5). The associated risk factors are lack of expertise of the supplier with the activity, task complexity, measurement problems, interdependence of the activities, supplier financial stability, and supplier size. The first four factors were described earlier. Supplier financial stability was a selection criterion and was considered prerequisite to becoming a potential BPX supplier. The probability of choosing an unstable supplier was moderate at the beginning (4). The selection process lowered this risk by thoroughly evaluating supplier finances and rejecting unstable candidates (2). The selection process invited both large and small providers to participate and the probability of selecting a smaller firm was moderate (4).

In this case, the main risk management tool was "not to rely on a single supplier. Having an alliance deflected the impact of a service slowdown by spreading services between three companies and mitigated it by keeping suppliers conscious of the company's ability to switch to another supplier. In order to mitigate the interdependent character of the activities, BPX decided to assign clear area of responsibilities. The company tried to mitigate the risk factor by requiring one supplier to take primary responsibility for problem-solving at each site (3).

\section{BPCC Contract.}

In June 1992, the BP Corporate Center (BPCC) undertook the complete outsourcing of its data center management and of its telecommunications. The implementation of this strategy took nine months and involved negotiations with three suppliers: two for site services and one for WAN services. The outsourcing agreement also covered some computing for each of BP's business groups. But unlike the BPX project, the BPCC project did not cover application development and support.

BPCC wished to replicate the distribution of client-supplier responsibilities it had implemented in the BPX contract. And even as the management at BPCC stated formally it aimed at building a partnership with its suppliers, a detailed examination of the contract design and management leads one to conclude that it ended up with mostly a facilities management relationship, which is fairly common in IT outsourcing. 


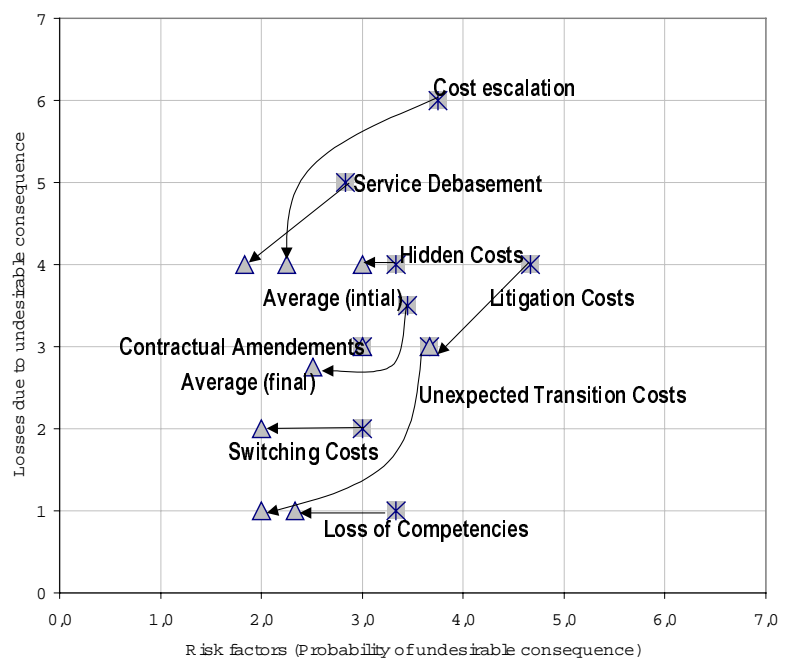

Figure 2 BPCC Contract

Risk assessment and management of the BPCC contract was greatly facilitated by the experience acquired in the BPX contract. Although these were separate units, the BPCC team worked closely with the BPX team: many of the decisions and directions taken by the BPCC team reflected BPX ideas and experience. It is not surprising, then, that the final BPCC contract resembled the XIT contract.

Risk exposure and risk management. Because many risk factors were deemed by the BPCC team to be present, and the expected consequences rather important, the risk exposure of the BPCC contract was globally high. Yet, as will be seen, the overall level of risk exposure in the end was markedly lower than in the BPX contract. The characteristics of the project. The way it was managed, and the learning that occurred through the BPX contract are responsible for that.

The undesirable outcomes that were identified as both rather costly and highly probable are four: i) cost escalation; ii) quality debasement; iii) hidden costs; and iv) unexpected management and transition costs. This made for a rather high global risk exposure of the overall BPCC project (see Figure 2).

Cost escalation was seen et the outset as a major source of loss (6). It was expected to be likely mainly because of measurement problems (initially evaluated as very high, 6, and managed to a moderate-high level,5). First, legal restrictions prevented BP from implementing end-to-end service level agreements. This created a room for supplier opportunism which led to significant difficulties. For instance, BP found that there were instances when suppliers marked up the cost of equipment required by the project. Second, the relative lack of contract management experience, which was felt to be a serious problem (6) at BPCC made BP more vulnerable to supplier opportunism. As was indicated above, the management at BPCC knew that this inexperience represented a major threat and reacted by observing, consulting, and to some extent implicating the BPX team, thus considerably reducing the probability of undesirable consequences (1). 
BPCC's team had one full time member: the project manager. This person had closed ties to the XIT's management and was keen to learn from BPX's experience. All the other members of the team were from the BPCC Corporate Information and Telecommunications (CIT) Department and had responsibilities for the normal operations of CIT. The team recognized early on that it had very little experience or knowledge of outsourcing. It thus thoroughly reviewed the BPX process and undertook a systematic benefits and risk analysis of the BPCC project. It also worked closely wit the BPX team to learn from their experience. Finally, to negotiate from a position of knowledge, it decided to benchmark existing IT services over a six-month period prior to the negotiation.

Also to counter the undesirable consequences of cost escalation, the contract focused on precise cost targets. A reduction of costs was the principal objective of the operation. Cost reductions thus superseded all other outsourcing goals and became immediately the suppliers' primary concern. Some incentives were also provided to suppliers to find ways to further reduce costs. And, as in the BPX contract, the BPCC strategy involved dealing with a consortium of suppliers, thus putting each in competition with the others, and alleviating the measurement problems by introducing a form of benchmarking.

Service debasement, as with the BPX contract, was considered the greatest threat after cost escalation ex ante (5). A senior executive at BPCC found that $65 \%$ of users felt that the quality of IT services had declined since outsourcing. Here again, measurement problems are the principal source of risk. For instance, as time passed and the set targets had been met, BP ceased to be seen as a "preferred customer" and the quality of the personnel assigned to the BPCC contract was felt to be inadequate or deteriorating. Lack of expertise of the supplier, always a potential factor, was evaluated as being less important than in the BPX contract because the BPCC contract was more focused and required a narrower breadth of know how from the supplier, and because of the experience gained in the supplier selection process by the BPX management team (1). Another risk factor associated with quality debasement is the level of interdependence between the outsourced activities and those kept in-house. Since the contract involved telecommunications links and data centers, interdependence was initially seen as being less than in the BPX contract (4). Yet, problems linked to the interdependence of the activities develop. For example, if one supplier needed something from another, he would issue a request and wait for a reply, secure in the knowledge that he had lived up to his responsibilities: a slowdown of operations would ensue. Poor problem resolution also appeared as a result of a decline in communication between the users and the service providers on the one hand, and a decline in supplier staff skills on the other hand. Interdependence was dealt with as in the BPX contract (thus reducing the the score of that factor to 2).

In addition, an unintended consequence of the focus on costs reduction was a reduction in the level or quality of effort of the suppliers leading to service debasement, or to a lack of attention to proper service improvements. As a result, when the BPCC staff became aware of the risk of a decline in quality, it increased its monitoring and the staff stayed closer to the projects, thus increasing the costs of managing the transaction. As a result, the level of undesirable consequences associated with service debasement was brought down, but only marginally so (4). 
The presence of hidden service costs -when the client assumes that many services are in the contract but finds they are not-- was also considered rather likely, and potentially damaging (4), but much less so than in the BPX contract: both the level of uncertainty and the complexity of the task were considered much less important in the BPCC context. The level of uncertainty concerning the needs was considered the prime factor leading to hidden costs (3), yet it was felt to be lower given the nature and the scope of the activities being outsourced. But measurement problems (7), which were also considered serious in the BPCC contract combined with moderate uncertainty to make hidden costs a threat. In the end, little could be done to alleviate that source of loss (4).

Finally, unexpected management and transition costs (3) were also identified as a potential source of damages to BP, particularly since BPX had experienced some problems in the transition phase of the project. But the BPCC team was aware of the transition difficulties encountered during the BPX contract. It thus developed a coherent human resources plan which addressed the problems of moved or transferred employees. This resulted in comprehensive and detailed planning.

Contract renegotiations costs (3), disputes and litigations (4), supplier switching costs (2), and loss of organizational competencies (1) were also considered as potential threats. But the level of undesirable consequences attached to these, combined with a lower probability of occurrence produced a lower level of risk exposure.

Thus, learning from BP's prior experience with outsourcing, comprehensive planning, specifying precise and hard costs targets, and increased monitoring were the main tools deployed by the BPCC management team to manage IT outsourcing risks.

\section{BP Global contract.}

In 1998, BP decided that a single supplier would replace the fragmented assortment of suppliers which existed, regrouping all infrastructure and the different contracts (BPX and BPCC). In the arrangement, the supplier would provide similar IT environments in all the regions where BP operates. A five year contract was envisaged.

Risk exposure and risk management. The risk level is presented in Figure 3. Two evaluations were done, one evaluating the ex ante risk, and a second one evaluating the final risk level, once the risk management mechanisms are implemented. From Figure 3, one can observe that the riskiest aspect is linked to switching costs. By using only one supplier, a costly lock-in situation can easily appear. Considering the extent of activities included in the contract, this would be extremely costly (7). The factors associated to this negative consequence are also significant. The diversity of material, the size and the inherent complexity of such global operations made the assets moderately specific (4). This was made apparent by the very small number of suppliers available. BP evaluated that only two suppliers in the world were capable of providing services on such a scale (rating $=6$ ). The contract is huge (7) but the activities included in the contract are moderately interdependent with the rest of BP's activities (4). To reduce potential problems due to the lock-in situation, BP included a one-year notice of termination. One year is considered the minimum time it would take to transfer the contract. This was a major source of disagreement 
with the supplier but BP considered it too important to give up this clause. This helped reduce the impact of negative outcome from 7 to 4 .

Other elements where potential negative consequences are high are cost escalation and transition costs. BP's approach toward the cost aspects is not the same as it was in earlier contracts. While in its earlier contracts, BP had tried to squeeze out costs, actually reducing the cost of services over time, with this contract, costs have been defined for five years. This effectively ensures that everyone knows what their costs will be over this period of time. This is considered a "step back" in control over this aspect of the contract but the company realized it had pushed its suppliers too hard in previous contracts. The current contract defines the commercial structure, reporting requirements, metrics and quality incentives that will be used for this contract. Due to the extent of services rendered, costs are important and escalation would be very costly. The factors linked to cost escalation are numerous but many are very low. BP has an extensive expertise and experience with outsourcing (1), the supplier is very experienced with the activities included in the contract, being one of the largest in the world. The supplier is also one of the largest outsourcer in the world. It is very competent in managing contractual relationships (1). The most threatening factor is the presence of measurement problems. Because of the scope and the variety of activities, measuring each one will be arduous (5). Many mechanisms were established to reduce this problem. Among the most important one is the opting out clause, which prevents the extra costs to be extracted over a long period (revised level: 4).

To reduce measurement problems, benchmarking will be conduced on a regular basis. Measurement will be done at two levels: global measures specify a set of global metrics, targets, and common global processes which will be established and measured for such processes as: problem management, infrastructure change control, messaging management, server management, and client (PC) management. Service levels will be described in customer-facing terms. Local Measures will be locally selected from a "service line menu". Ten metrics have been identified and regions will be allowed to pick any three of these to be measured. These enable regions to monitor their "hot buttons", i.e., the areas which are causing them the most concern. Measures used will stress standardization across the company to help ensure consistent governance (revised level:2).

Transition costs could also bring severe penalties (6)due to the extent of the activities to transfer. They would come with service deterioration and business disruption. Such disruption would cause severe problems and major losses would be incurred. In fact, some people interviewed believed that some problems were was already occurring. Kevin Carr noted that key supplier staff no longer want to work on the BP account because it isn't going to benefit their careers. There is also friction with existing suppliers because they believe EDS will try to hire some of these staff away from them. And several supplier staff have simply resigned in the weeks following the EDS announcement. The most important factors linked to transition costs are linked to the legal environment. Transferring activities to EDS presents different risks in different regulatory situations (4). Even if the contract is understood as global by the partners, conducting business in 


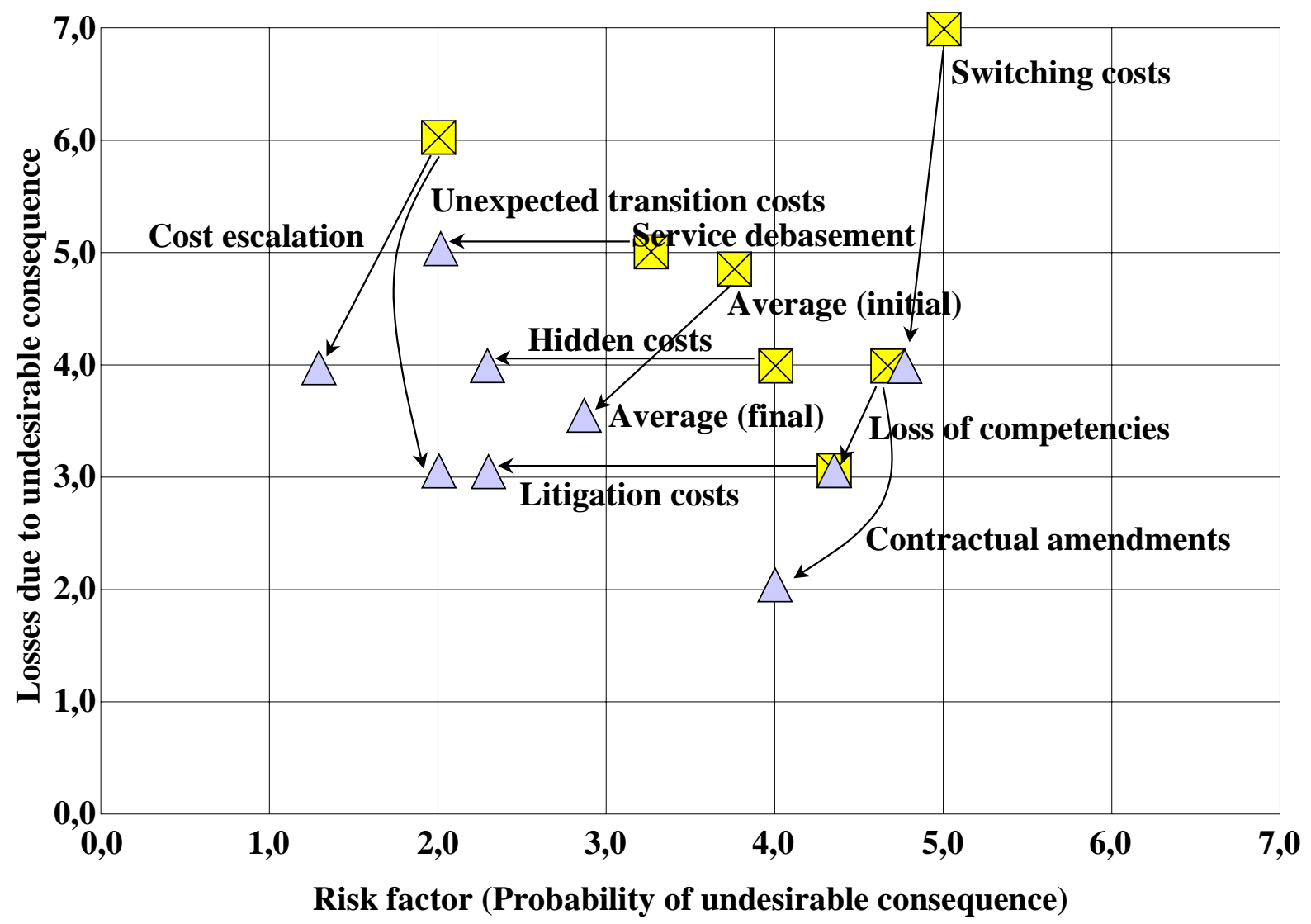

Figure 3 BP Global Contract

different countries increases the complexity of the legal environment. However, BP has extensive experience with outsourcing (1) and a thorough of the activities involved (1). To reduce the transition related problems, BP increased the planning efforts, developing an "exit strategy" for all suppliers which will clarify their responsibilities and the timing of the changeover. Other ways of reducing this risk factor include: clear planning and communication; doing one implementation at a time; development of a phased transition plan with clear accountabilities; providing incentives to suppliers and key staff; contingency planning; using additional resources; and good relationship management with all suppliers. In this way, unexpected transition costs should be reduced (3). Interestingly, the overall cost of transition is not necessarily reduced, but the unexpected part of it is.

Hidden costs were deemed significant but limited by contract design (4) since most costs will be bundled into one single cost per month. Some factors leading to such costs were important. The needs are relatively certain (3), however measurement problems were substantial (5) but, as discussed earlier, the contract reduced them significantly (2). The services are also relatively complex (4) but this complexity is mostly transferred to the supplier, leaving to him the micromanagement task. This reduced the complexity on the client side (2). Reduction of quality would 
be very damageable for BP. Most BP activities relied on IT (5). Most drivers of service debasement are moderate. The supplier is large (1), very experience with the activities (1) and with outsourcing (1). The activities, involving operations but excluding software development are somewhat complex (4), fairly interdependent with the rest of the firm's activities (4), and linked to core competencies (4). As mentioned earlier, the complexity, for the client, was reduced and transferred to the supplier (2). Measurement problems were initially high (5) but reduced in the final setting (2). The supplier had unstable financial situation (5) but further assessment clarified this situation (3).

The last elements which presents significant risk are contractual amendments and litigation. The first could be costly (4) simply because of the scope of the agreement. Technological discontinuity are expected (7), work is complex (4) and uncertainty is present (3). To reduce the impact of these changes to contracts, BP is managing the risk in two ways. First, some upgrades have been built into the existing contract and EDS will be responsible for making some investments in technology improvements. Second, in order to better control its own costs, BP and EDS have agreed that most technology replacement will be handled in a separate contract. This will enable BP to see exactly what it is paying for. Jorge Arceniegas noted that clear measures which are comparable over time are the best ways to control costs. This is perceived as a sequential contracting mechanism. Litigation would be costly (3). Key drivers of litigation were cultural fit of the partners (4) legal environment (4) and measurement problems (initial: 5, final: 2). Not much could be done for legal environment. To lower the likelihood of problems in the area of cultural fit, BP asked suppliers, during the supplier selection process, for references from other customers and went out to see how they worked with these other companies. Some of the things they were looking for was: could they tell who was a supplier and who was a client staff member; how much freedom to act supplier staff had; and their degree of innovation on the job. This enabled BP to assess to what extent EDS would be able to adjust to BP's culture (final evaluation: 1).

\section{Analysis}

We first discuss the micro-structure of the three cases, then compare the strategy used in each case to deal with outsourcing risks.

As is generally expected from a case study approach, the detailed analysis of the three cases shows that every contract has its peculiarities, every contract -though conducted within the same organization- presents different threats and opportunities. Yet, the BPX and BPCC contracts show many similarities and interconnections.

In both cases, the most feared undesirable consequences are cost escalation, hidden service costs and service debasement. And in both cases, measurement problems appear to be the most serious related factor of risk. Yet the BPX contract is characterized by both a rather high level of undesirable consequences and a high probability of occurrence. This is attributable to the scope and characteristics of the BPX contract: it covered all BP exploration activities around the globe and covered systems development, in addition to date center management, telecommunications 
and maintenance. Hence the scores associated to the transaction-specific risk factors: uncertainty, measurement problems, task complexity, asset specificity, etc. Of a more limited scope, both spatially and functionally, the BPCC contract is clearly a much less risky endeavor.

In addition, as the above analysis of each case has suggested, learning occurred through the management of the BPX contract, which translated into both lower probabilities for the undesirable consequences and better risk management strategies. The mean value of the ex ante probability of occurrence of all undesirable consequences falls from 5.1 to 3.4 when one moves from the BPX to the BPCC contract. The ex post probability falls from 3.6 to 2.5.This is suggests two things: the BPX team was rather successful in bringing down the probability of a major mishap in managing the BPX contract, and this experience helped the BPCC team, in particular in the planning, assessment and strategy phase of the project. An indication of that is the score associated with the lack of expertise factor in the BPCC case, which drops (ex ante) from 6 to 1 , mainly because of learning.

On the other hand, the Global BP contract appears to present undesirable consequences similar to those in the BPX contract, thus larger than in the BPCC contract, but with a lower probability of occurrence. Although the scale of activities in the BP Global contract is quite impressive, its scope is narrower than in the BPX case, for it excludes development. It also contains one distinguishing features: it relies on a single supplier. This can be seen as a technological constraint dictated by the desire to provide similar IT environments everywhere. This characteristic explains why the dominant fear, in the BP Global context, was that of being "locked in" with that supplier. Thus the prevalence of switching costs and transition and management costs.

When comparing the global management strategies used in all three contexts, we clearly see that efforts were directed at reducing the very high probability that a major problem would develop (such as cost overruns or hidden service costs) in the BPX contract, whereas in the BP Global contract, most efforts were directed at reducing the losses.

This should not come as a surprise: the overall probability of losses was significantly higher in the former case (5.1 compared to 3.8), with comparable (average) loss levels (5.1 versus 4.9). Hence a strategy aimed at reducing that probability would bring greater benefit. There are reasons to believe that the marginal cost of reducing the probability of an undesirable consequence increases rapidly as this probability is reduced: thus targeting the high probability consequences and trying to have an impact on the underlying factors makes sense. Likewise, the BP Global team started off with moderate probabilities of facing undesirable consequences. Yet, some undesirable outcomes entailed potentially very heavy losses: the strategy adopted in this case aimed principally at reducing the magnitude of the losses. The average loss level was thus curtailed to 3.5 from an initial level of 4.9. The expected losses arising from switching suppliers or from unexpected transition costs were quite remarkably cut down by careful planning and contract design. In comparison, the mean expected loss in the BPX contract was reduced from 5.1 to 4. Notice that risk management also brought down the probability of loss in the BP Global contract (from 3.8 to 2.9 ). 
Again, this suggests that the BP management read very clearly the situation and deliberately sought the least cost alternative to managing risks. Concentrating efforts on the probability side in the first situation, and on the loss side in the second is coherent with the global evaluation of the two contracts.

That BP accepted to born the remaining risk only shows that it expected to reap benefits from those transactions (mainly cost reductions). Whether the expected benefits justified the overall level of risk borne by the company is beyond the reach of this analysis. It can only be argued that the objective of outsourcing risk management is to minimize the expected cost associated with the contractual risks of an outsourcing strategy. These costs are made up of two components: the expected losses of undesirable consequences and the costs of managing risks. Once a position of maximum gains is obtained for a given transactional context, it remains to be seen, on a strategic level, if the remaining risk level is consistent with the (operational) gains that are expected.

If our analysis of those three outsourcing contracts at BP can not tell us if the decision was efficient in a risk-return framework, it shows that risk management at BP consisted in a very articulate and deliberate exercise which proved successful in bringing down the global risk exposure of the company to IT outsourcing risks. Moreover, by following BP through the three contracts, one is struck by the perfecting of their risk management strategy. Learning does occur, and is put to use in the management of future contracts.

\section{Conclusion}

Our analysis illustrates that each IT outsourcing contract gives rise to different manifestations of risk. The sources of risk (factors), and their prevalence, are equally context dependent. This diversity should lead managers to adopt different risk management strategies, depending on the context (here defined as the characteristics of the client and the supplier and the transactionspecific characteristics). The findings of this study corroborate this assertion: in some situations, the strategy aimed at reducing the probability of occurrence of undesirable consequences, in others, it focused on lowering the impact of the potential undesirable consequences. And, sometimes, it tried to accomplish both.

The results support the risk analysis framework. First, all three contracts could be described in terms of negative events faced by the client and relative likelihood for each event. This likelihood of each event was approximated using associated factors. Such a description directly suggests corresponding management mechanisms, usually taking the form of contractual mechanisms, to reduce the risk level.

BP appears to be a particularly interesting organization for conducting such an analysis. The firm has a strong tradition and a rather formal process for dealing with IT risks. As a result, the attention its managers paid to risk exposure, their experience with risk management in general, and BP's organizational routines enabled the firm to undertake very risky IT outsourcing projects. By properly managing risk, BP managers deliberately chose to bear some risk, while exerting efforts to maintain their risk exposure within tolerable bounds, given the strategic objectives of the operation. They thus did not rely on fate and chose to manage risk. 
The case showed that some choices could be seen as compromises. A given risk management mechanism could lower one type of risk while increasing another one. For example, when BP decided in the third contract to deal with a single supplier, risks related to measurement problems were less probable. However, this was done at the expense of an increase in the risk of lock-in. As managers become more aware of the control they have on the risk profile of their IT outsourcing strategy, they should bear more responsibility over the outcomes.

\section{References}

[1] Alchian, A .A., Demsetz, H., " Production, Information Cost and Economic Organization ," American Economic Review, 62, December 1972, pp. 777-795.

[2] Anderson, J., Narasimhan, R., "Assessing Implementation Risk : A Methodological Approach," Management Science, Vol.25, No.6, June 1979, pp. 512-521.

[3] Arrow, K.J., Individual Choice under Certainty and Uncertainty, Harvard University Press, Cambridge, 1984.

[4] Aubert, B.A., Dussault, S., Patry, M., Rivard, S., "Managing the Risk of IT Outsourcing, " Proceedings of the Thirty-Second Hawaii International Conference on System Sciences, Organizational Systems and Technology Track, Hugh Watson editor, Hawaii, 1999 (CDROM).

[5] Aubert, B.A., Patry M., Rivard, S., “Assessing the Risk of IT Outsourcing” Proceedings of the Thirty-First Hawaii International Conference on System Sciences, Volume VI, Organizational Systems and Technology Track, Hugh Watson editor, Hawaii, 1998, pp. 685-693.

[6] Aubert, B.A., Patry, M., Rivard, S., "A Tale of Two Outsourcing Contracts," Cahier du GReSI 97-05, 1997.

[7] Barki, H., Rivard, S., Talbot, J., "Toward an Assessment of Software Development Risk," Journal of Management Information Systems, Volume 10, Number 2, Fall 1993, pp. 203-225.

[8] Barzel, Y., " Measurement Cost and the Organization of Markets ,"Journal of Law and Economics, 25, April 1982, pp. 27-48.

[9] Bernstein, P.L., Against the Gods - The Remarkable Story of Risk, John Wiley \& Sons, New York, 1996.

[10] Boehm, B, B.W., Software Risk Management, IEEE Computer Society Press, Los Alamitos, California, 1989.

[11] Cross, J., "IT Outsourcing : British Petroleum's Competitive Approach," Harvard Business Review, May-June 1995, pp. 95-102.

[12] Dorn, P. "Selling One's Birthright," Information Week, No.241, October 16, 1989, p. 52. 
[13] Earl, M.J., "The Risks of Outsourcing IT," Sloan Management Review, Spring 1996, pp. 26-32.

[14] Gack, G., "A Cautionary Tale," Computerworld, Sep 12, 1994, p. 135.

[15] Grossman, S., Hart, O., "The Costs and Benefits of Ownership :A Theory of Vertical and Lateral Integration, " Journal of Political Economy, 94, 1986, pp. 691-719.

[16] Lacity, M.C., Hirschheim, R., Information Systems Outsourcing, John Wiley \& Sons, New York, 1993.

[17] Lacity, M.C., Willcocks, L.P., Feeny, D.F., "IT Outsourcing : Maximize Flexibility and Control," Harvard Business Review, May-June 1995, pp. 84-93.

[18] Langlois, R.N., Robertson, P.L., "Networks and Innovation in a Modular System: Lessons from the Microcomputer and Stereo Component Industries, Research Policy, vol. 21, 1992, pp. 297-313.

[19] Linerooth-Bayer, J., Wahlstrom, B., "Applications of Probabilistic Risk Assessments : the selection of Appropriate Tools," Risk Analysis, Vol.11, No.2, 1991, pp. 239-248.

[20] March, J., Shapira, Z., "Managerial Perspectives on Risk and Risk-Taking, " Management Science, Vol.33, No.11, pp. 1404-1418.

[21] Nam, K., Rajagopalan, S., Rao, H.R., Chaudhury, A., "A Two-Level Investigation of Information Systems Outsourcing," Communications of the ACM, Vol.39, No.7, July 1996, pp. 37-44.

[22] Nelson, P., Richmond, W., Seidman, A., "Two Dimensions of Software Acquisition," Communications of the ACM, Vol.39, No.7, July 1996, pp. 29-35.

[23] O'Leary, M., "The Mainframe Doesn’t Work Here Anymore," CIO, Vol.6, No.6, June 1990, pp. 77-79.

[24] Prahalad, C.V., Hamel, G., "The Core Competence of the Corporation," Harvard Business Review, May-June 1990, pp. 79-91.

[25] Roberts, L., Process Reengineering, ASQC Quality Press, Milwaukee, Wisconsin, 1994.

[26] Roll,R., "The Hubris Hypothesis of Corporate Takeovers,"Journal of Business, April 1986, pp. 197-216.

[27] Sappington, D., "Incentives in Principal-Agent Relationships," Journal of Economic Perspectives, Vol.5, No.2, 1991, pp. 45-68.

[28] Williamson, O.E., The Economic Institutions of Capitalism, The Free Press, New York, 1985. 


\section{Liste des publications au CIRANO *}

\section{Cahiers CIRANO / CIRANO Papers (ISSN 1198-8169)}

99c-1 Les Expos, l'OSM, les universités, les hôpitaux : Le coût d'un déficit de 400000 emplois au Québec — Expos, Montréal Symphony Orchestra, Universities, Hospitals: The Cost of a 400,000-Job Shortfall in Québec / Marcel Boyer

96c-1 Peut-on créer des emplois en réglementant le temps de travail? / Robert Lacroix

95c-2 Anomalies de marché et sélection des titres au Canada / Richard Guay, Jean-François L'Her et Jean-Marc Suret

95c-1 La réglementation incitative / Marcel Boyer

94c-3 L'importance relative des gouvernements: causes, conséquences et organisations alternative / Claude Montmarquette

94c-2 Commercial Bankruptcy and Financial Reorganization in Canada / Jocelyn Martel

94c-1 Faire ou faire faire : La perspective de l'économie des organisations / Michel Patry

\section{Série Scientifique / Scientific Series (ISSN 1198-8177)}

2000s-31 IT Outsourcing Risk Management at British Petroleum / Benoit A. Aubert, Michel Patry, Suzanne Rivard et Heather Smith

2000s-30 A Resource-Based Analysis of IT Outsourcing / Vital Roy et Benoit Aubert

2000s-29 The Impact of Government-Sponsored Training Programs on the Labor Market Transitions of Disadvantaged Men / Lucie Gilbert, Thierry Kamionka et Guy Lacroix

2000s-28 Hope against Hope: Persistent Canadian Unions in the Interwar Years / Michael Huberman et Denise Young

2000s-27 The Impact of Human Resources Practices on IT Personnel Commitment, Citizenship Behaviors and Turnover Intentions / Guy Paré et Michel Tremblay

2000s-26 Organizational and Individual Determinants of Atypical Employment: The Case of Multiple Jobholding and Self-Employment / Gilles Simard, Denis Chênevert et Michel Tremblay

2000s-25 Les déterminants organisationnels et individuels de l'emploi atypique : Le cas du cumul d'emplois et du travail autonome / Gilles Simard, Denis Chênevert et Michel Tremblay

2000s-24 L'engagement organisationnel et les comportements discrétionnaires : L'influence des pratiques de gestion des ressources humaines / Michel Tremblay, Philippe Guay et Gilles Simard

2000s-23 Environmental Risk Managemant and the Business Firm / Bernard Sinclair-Desgagné

2000s-22 Temporal Aggregation of Volatility Models / Nour Meddahi et Éric Renault

2000s-21 Le projet Harmonie / Richard Landry et Suzanne Rivard

\footnotetext{
* Vous pouvez consulter la liste complète des publications du CIRANO et les publications elles-mêmes sur notre site Internet à l'adresse suivante :
}

http://www.cirano.umontreal.ca/publication/documents.html 